\title{
Single Nucleotide Polymorphisms (SNPs) in Exon 6 of Lecithin Cholesterol Acyltransferase (LCAT) Gene in Indonesian Local Sheep
}

\author{
Hidayati $^{a, c, *}$, C. Sumantri ${ }^{b}$, R. R. Noor ${ }^{b}$, \& R. Priyanto ${ }^{b}$ \\ aStudy Program of Animal Production and Technology, Faculty of Animal Science, Graduate School, \\ Bogor Agricultural University \\ aDepartment of Animal Production and Technology, Faculty of Animal Science, Bogor Agricultural University \\ Jln. Agatis, Kampus IPB Darmaga, Bogor 16680, Indonesia \\ 'Breeding and Genetic Laboratory, Agricultural and Animal Science Faculty \\ State Islamic University of Sultan Syarif Kasim Riau \\ Kampus II Raja Ali Haji JL. HR. Soebrantas KM 15 Panam, Pekanbaru 28293, Indonesia \\ (Received 03-02-2014; Reviewed 05-03-2014; Accepted 01-07-2014)
}

\begin{abstract}
Lecithin cholesterol acyltransferase (LCAT) is a soluble enzyme that converts cholesterol and lecithin to cholesteryl esters and lysolecithins on the surface of high density lipoprotein and plays an important role in lipoprotein metabolism. The research was aimed to explore single nucleotide polymorphisms of LCAT gene in Indonesian local sheep. A total of 118 genomic DNA of Indonesian local sheep were used in this research, consisted of Sumatera Thin Tail (43 heads), Garut (19 heads), Javanese Thin Tail (17 heads), Javanese Fat Tail (6 heads), Rote Island (7 heads), Kissar (7 heads), Sumbawa (10 heads), and Lembah Palu ( 9 heads). Polymerase chain reaction was used to amplify genomic DNA for exon $6(250 \mathrm{bp})$ and direct sequencing method was used to identify polymorphism sequences. The sequences were analyzed with BioEdit and MEGA 5.2 software. The BLAST sequence was obtained from Gene Bank GQ 150556.1. The results showed three novel SNPs, i.e. c.742C $>T$, c.770 $\mathrm{T}>\mathrm{A}$ and $\mathrm{c} .882 \mathrm{C}>\mathrm{T}$. Substitution of cytosine to thymine c.742 is a synonymous mutation; thymine to adenine c.770 and cytosine to thymine c.882 are non-synonymous mutations. Polymorphisms of LCAT gene exon 6 was found in Sumatera Thin Tail, Javanese Thin Tail, Javanese Fat Tail, Garut, Lembah Palu, and Rote Island.
\end{abstract}

Key words: LCAT gene, SNPs, sheep, sequences, PCR

\section{ABSTRAK}

Lecithin cholesterol acyltransferase (LCAT) adalah soluble enzyme yang mampu mengonversi kolesterol dan lesitin menjadi ester kolesterol dan lisolesitin pada permukaan high density lipoprotein dan berperan dalam metabolisme lipoprotein. Penelitian ini bertujuan untuk mengeksplorasi single nucleotide polymorphisms (SNPs) gen LCAT domba lokal Indonesia. Total 118 DNA genom domba lokal Indonesia yang terdiri atas: Ekor Tipis Sumatera (43 ekor), Garut (19 ekor), Ekor Tipis Jawa (17 ekor), Ekor Gemuk Jawa (6 ekor), Pulau Rote (7 ekor), Kissar (7 ekor), Sumbawa (10 ekor), dan Lembah Palu (9 ekor) digunakan dalam penelitian ini. Amplifikasi DNA genome menggunakan polymerase chain reaction pada fragmen ekson 6 gen LCAT $(250 \mathrm{bp})$ dan metode direct sequencing digunakan untuk mengidentifikasi keragaman sekuens. Hasil sekuens dianalisis menggunakan software Bioedit dan MEGA 5.2. Sekuens kemudian disejajarkan dengan metode Clustal W dan selanjutnya urutan BLAST diperoleh dari gene bank GQ150556.1. Hasil penelitian menunjukkan bahwa ditemukan tiga SNPs baru, yaitu pada posisi basa c.742C $>\mathrm{T}$, c.770 T>A, dan c.882C $>\mathrm{T}$. Substitusi sitosin menjadi timin c.742 merupakan synonymous mutation; timin menjadi adenin c.770 dan sitosin menjadi timin c.883 merupakan non synonymous mutation. Keragaman gen LCAT ekson 6 ditemukan pada populasi Ekor Tipis Sumatera, Ekor Tipis Jawa, Ekor Gemuk Jawa, Garut, Lembah Palu, dan Pulau Rote.

Kata kunci: gen LCAT, SNPs, domba, sekuens, PCR

${ }^{*}$ Corresponding author:

E-mail: yati_suska@yahoo.com 


\section{INTRODUCTION}

Indonesia has a wide variety of sheep that are scattered in various areas with good breeding and establish certain morphological characters. According to habitat and morphometric characters, Indonesian local sheep was grouped into 5 clusters, i.e. Garut, Javanese Thin Tail (Jonggol), Fat Tail (Kissar, Rote Island, and Sumbawa), Donggala and Javanese Fat Tail (Indramayu and Madura) (Sumantri et al., 2007). Sheep is an economically important animal in Indonesia, especially provide fresh meat, sacrificial animals (Inounu, 2011), social, culture and source of genes for use in the improvement of local sheep through crosses between them and or exotic sheep (Sumantri et al., 2007). According to FAO (2002), local livestock is important to be protected because they adapt to local environment and low quality feed and are more resistant to local diseases and parasites. Indonesian local sheep had a high diversity based on morphological characters (Sumantri et al., 2007), and microsatellite analysis (Sumantri et al., 2008a; Jakaria et al., 2012).

Sheep is one of the meat-producing livestocks in Indonesia. However lamb is relatively less attractive to some communities in Indonesia. Lamb consumption is still very low, around $5 \%$ that is equivalent to 0.24 g/capita/year (Inounu, 2011). The low consumption of lamb is caused by a relatively high price, a distinctive odor that is difficult to remove, and the public perceptions that lamb has high cholesterol and saturated fatty acid. They are concerned by health factors, due to largely statements from the medical profession that lamb may contain too much saturated fatty acid (SFA) and trans mono unsaturated fatty acids (MUFA), which can be major risks for the development of coronary heart disease. The composition of the SFA, trans fatty acids, and dietary cholesterol were main factor to mortality rate determining differences on heart disease in seven countries (Kromhout et al., 1995).

The content of cholesterol is an important assessment of the consumer to consume lamb because it can affect health status. Meat cholesterol and SFA: poly unsaturated fatty acid (PUFA) ratio, are measures for providing "ASUH food" and to increase competitiveness to fulfill domestic market. Throughout the life of livestock, body fat was increased and the fatty acid composition also changed (Wood et al., 2008). SFA and MUFA contents were increased faster than PUFA due to increased of fat content, caused PUFA/SFA ratio would be decreased (De Smeet et al., 2004). Cholesterol content of meat sheep is not effected by diet, breed (Costa et al., 2009) and increased weight and age at slaughter (Wheeler et al., 1987).

Previous studies showed that cholesterol and marbling quality are regulated by functional genes. Deposition of fat in the muscle was determined by a balance of between anabolic and catabolic processes such as lipogenic and lipolytic, as well as transport of fatty acid and total of fatty acid used. The balanced of the processes was determined by the amount of fat consumed, de novo fat synthesis, triacylglycerol synthesis, lipids degradation and fatty acid transport (Zhao et al., 2010).
Lecithin cholesterol acyltransferase (LCAT) is a central enzyme in the extracellular metabolism of blood lipoproteins. This enzyme is synthesized in the liver (Kaplanova et al., 2010; Crisa et al., 2010), brain and testes (Reinshagen et al., 2009) and then secreted into the blood plasma. This enzyme converts cholesterol and lecithin into cholesterol ester and lysolecithin on the surface of high density lipoprotein (HDL), especially in the process of reverse cholesterol transport (Kaplanova et al., 2010; Crisa et al., 2010). The absence of this enzyme causes the accumulation of free cholesterol in the blood and tissues (Kaplanova et al., 2010). The enzyme is encoded by LCAT gene that was located in choromosome $14^{\text {th }}$ in Ovis aries. This gene consists of 6 exons and 5 introns and exon 6 is the longest exon with the length of 559 bp (Gene Bank with Accession No.GQ.150556.1).

Single Nucleotide Polymorphism (SNP) is a DNA sequence variation that arises when a single nucleotide (A, T, C or G) is different from the sequences generally. Dunner, et al. (2013) stated that SNP within candidate gene have been tested for predictive value for carcass traits and some commercial tests based on SNP marker panels are being proposed to breeders for genotype animals. The genomic selection currently used to estimate breeding values for quantitative traits due to small population sizes and lack of high accuracy estimated breeding values (EBV). Therefore, genomic selection can be improved by extending the panel of SNP in the candidate loci and better estimating SNP effects in different populations. In human, SNPs was associated with human genetic diseases (Lin \& Zeng, 2006).

Several previous studies have reported polymorphisms of LCAT gene in pig (Kaplanova et al., 2010; Qiao et al., 2010; Chalupova et al., 2012); dairy cow's (Loor et al., 2007) and sheep (Crisa et al., 2010; Moioli et al., 2012). Crisa et al. (2010) found one SNP in intron 2 g.181 $\mathrm{T}>\mathrm{C}$ and 2 SNPs in exon 6 c.806 G>A and c.1075 T>C. Mutation in this region negatively correlated to the fatty acid C 18:2 and positively correlated to milk production and stearic fatty acids affect the diversity of sheep's milk (Crisa et al., 2010; Moioli et al., 2012). Exploration of variability of this gene in Indonesian local sheeps has never been conducted. Therefore, exploration of LCAT gene on Indonesian local sheep was conducted to find Marker Assisted Selection (MAS) to produce and develop local sheep in the future.

\section{MATERIALS AND METHODS}

\section{Materials}

Fifty eight blood samples of Indonesian local sheep consisted of 44 samples from Padang (West Sumatera) and 14 samples from Garut (West Java) were collected by using venoject $3 \mathrm{~mL}$ from jugular vein. The blood samples were preserved in ethanol absolute 96\% with ratio of 1:1 and kept in room temperature for laboratory analysis. Other extracted DNAs deposited at the Genetics and Animal Breeding Laboratory were used in this study, i.e. Garut, West Java (Garut-Margawati meat type 5 heads), Javanese Thin Tail, West Java (Jonggol, 7 heads; MT Farm Bogor, 10 heads); Javanese Fat Tail, East 
Java (Situbundo, 6 heads), Rote Island (7 heads), KissarSouth West Molucas (7 heads), Sumbawa-West Nusa Tenggara (10 heads), and Donggala, Central Sulawesi (9 heads). A total of 118 samples of Indonesian local sheeps were used in this study.

\section{DNA Extraction}

Genomic DNA was extracted by using Phenol-chloroform technique (Sambrook et al., 1989) and modified by using buffer lysis cell $(250 \mu \mathrm{L} 1 \times$ STE, $40 \mu \mathrm{L}$ SDS and $10 \mu \mathrm{L}$ proteinase-K). The DNA was purified by adding $40 \mu \mathrm{L} 5 \mathrm{M} \mathrm{NaCl}, 400 \mu \mathrm{L}$ phenol chloroform and $400 \mu \mathrm{L}$ CIAA (Chloroform Iso Amyl Alcohol) and precipitated by using $40 \mu \mathrm{L} 5 \mathrm{M} \mathrm{NaCl}$ and $800 \mu \mathrm{L}$ ethanol absolute. The precipitation was washed once by adding $800 \mu \mathrm{L}$ of $70 \%$ ethanol and centrifuged with the speed of 12.000 rpm for $5 \mathrm{~min}$. The ethanol was discarded and evaporated, then the precipitated DNA was disolved in $100 \mu \mathrm{L}$ of $80 \%$ TE (Elution buffer).

\section{DNA Amplification and Direct Sequencing Method}

The DNA was amplified with Polymerase Chain Reaction (PCR). Each PCR reaction was made with cocktail $50 \mathrm{ng}(2-3 \mu \mathrm{L})$ DNA template, $0.25 \mu \mathrm{M}$ primer forward and reverse, $12.5 \mu \mathrm{L}$ Dream Tag Green Master Mix from Thermo Scientific \#K 1081 and $\mathrm{dH}_{2} \mathrm{O}$ up to $25 \mu \mathrm{L}$. The forward primer sequence was $\mathrm{F}^{\prime} 5$ GAGCAGCGCATGACGACAACG-3' and reverse primer sequence was F'5- AGGTGCTAGGAGTGGGCAGGC$3^{\prime}$. The position of primer forward and primer reverse in PCR product of LCAT gene were shown in Figure 1 and the length of PCR product yield was $250 \mathrm{bp}$ (Figure
2). Samples were initially denaturated at $95{ }^{\circ} \mathrm{C}$ for five minutes and followed by 35 cycles of denaturation at 95 ${ }^{\circ} \mathrm{C}$ for $45 \mathrm{~s}$, annealing at $62{ }^{\circ} \mathrm{C}$ for $45 \mathrm{~s}$ and extension at $72{ }^{\circ} \mathrm{C}$ for one min. Final extension was at $72{ }^{\circ} \mathrm{C}$ for $5 \mathrm{~min}$. GeneAmp PCR system 9700 and Master Cycler Personal 22331 Eppendorf were used for PCR amplification. PCR products were then separated on $1.5 \%$ agarose $/ 0.5 \times$ TBE, stained with $2.5 \mu \mathrm{L}$ of ethidhium bromide $(\mathrm{EtBr})$ and calibrated with 100 bp ladder marker. Electrophoresis chamber was run on 100 volt power supply for thirty minutes. Finally, the gel was visualized under UV transilluminator (Figure 2). The PCR product samples were then subjected to direct sequence analysis by dideoxy sequencing in $\mathrm{ABI} 3730 \mathrm{XL}$ automated DNA sequencer at the $1^{\text {st }}$ base laboratory Singapore.

\section{Data Analysis}

The results of sequence fragment of LCAT gene exon $6^{\text {th }}$ were analyzed with BioEdit (Hall, 2011), MEGA version 5.2 (Kumar et al., 2004) and POP GENE ver.1.31 (Yeh et al., 1999) software. The BLAST sequence was obtained from Gene Bank with accession number of GQ 150556.1. The analyzed sequence was required to ensure the fragment of LCAT gene of sheep and to find out the existence of mutation in LCAT gene and polymorphism in the sequence. (2000):

Frequency of gene was estimated by Nei \& Kumar

$$
x_{i}=\left(2 N_{i i}+N_{i j}\right) /(2 N) ; \quad x_{j}=1-x_{i}
$$

where:

$$
\begin{aligned}
& x_{i}=\text { frequency of } i \text { gene } \\
& x_{j}=\text { frequency of } j \text { gene }
\end{aligned}
$$

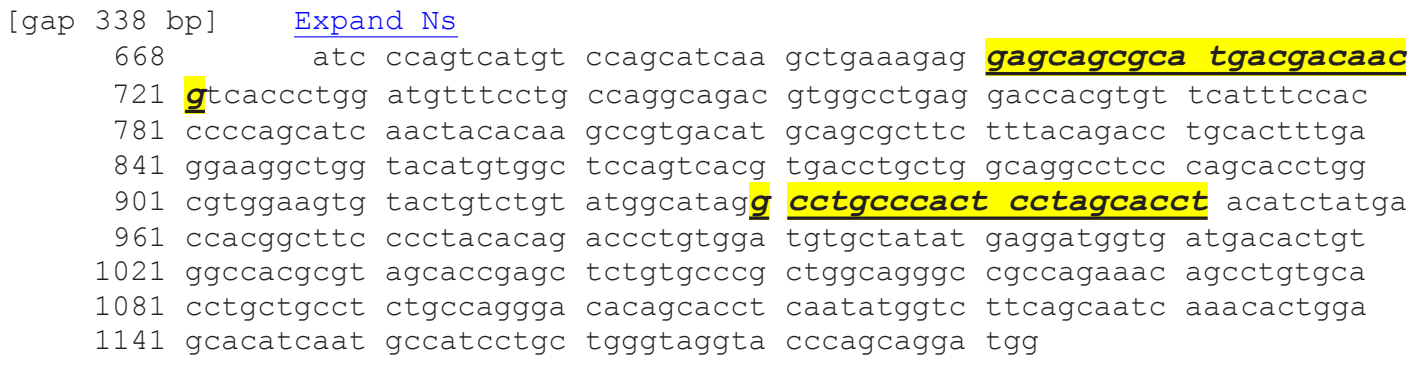

Figure 1. LCAT amplicon sequence, Genbank GQ.150556.1. The primers site were underlined and bold.

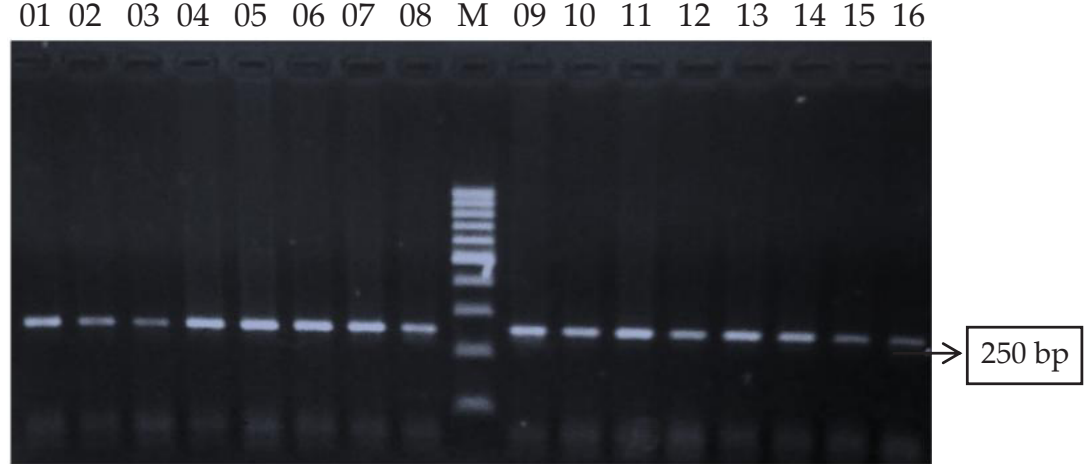

Figure 2. PCR amplification product of LCAT gene (250 bp); 0-16= Sumatera Thin Tail samples; m= DNA ladder 100 bp. 
$\mathrm{N}_{\mathrm{ii}}$ = number sample of ii genotype

$\mathrm{N}_{\mathrm{ij}}=$ number sample of ij genotype

$\mathrm{N}^{\mathrm{ij}}=$ number of sample

Frequency of genotypes was measured as by Nei \& Kumar (2000):

$X_{i i}=\left(N_{i i} / N\right) \times 100 \% ; X_{i j}=\left(N_{i j} / N\right) \times 100 \% X_{i j}=\left(N_{i j} / N\right) \times 100 \%$

where:

$X_{\mathrm{ii}}=$ frequency of ii genotype

$X_{\mathrm{ii}}=$ frequency of $\mathrm{jj}$ genotype

$X_{\mathrm{ij}}^{\mathrm{II}}=$ frequency of ij genotype

Deviation frequency genotype from Hardy

- Weinberg equilibrium was analyzed by chi square test ( $X^{2}$ test) as follows Nei \& Kumar (2000);

$$
\chi^{2}=\sum_{i=1}^{n} \frac{(0-E)^{2}}{E}
$$

where:

$X^{2}=$ chi square test

$\mathrm{O}=$ the observed numbers of frequency

$\mathrm{E}=$ the expected numbers of frequency

The observed heterozygosity $\left(\mathrm{H}_{\mathrm{o}}\right)$ and excepted heterozygosity $\left(\mathrm{H}_{\mathrm{e}}\right)$ were estimated with POPGENE 32 version 1.31 software (Yeh et al., 1999);

$H_{o}=\sum_{k}^{s} w_{k} \sum_{i \neq j}^{q} X_{k i j} ; \quad H_{e}=1-\sum_{k}^{s} W_{k} \sum_{i}^{q} x_{k i}^{2}$

where:

$H=$ the observed heterozigosity

$H_{e}=$ the expected heterozigosity

$w_{k}=$ size population relatively

$X_{k i j}=$ frequency of genotype AiAj, the k- population

\section{RESULTS AND DISCUSSION}

\section{Discovery of Single Nucleotide Polymorphisms of LCAT Gene}

One hundred and eighteen (118) sequences of Indonesian Local Sheep on LCAT gene encoding region 6 were aligned with a sequence of gene bank with accession number of GQ 150556.1. The results showed three point of mutations i.e. c.742C $>\mathrm{T}$, c.770 $\mathrm{T}>\mathrm{A}$, and c.882 $\mathrm{C}>\mathrm{T}$. The three SNPs were reconstructed nine diplotypes (Figure 3), dispersed in 8 breeds of Indonesian Local Sheep. Among them, the frequencies of three diplotypes were higher than 5\% i.e.: $\mathrm{H} 1 \mathrm{H} 1(66.10 \%), \mathrm{H} 1 \mathrm{H} 3$ (16.10\%) and H1H5 (5.08\%) (Table 1$)$. There is no published literature describing polymorphisms of LCAT gene exon 6 in Indonesian Local Sheep. In this research, three novel SNPs were detected among six sheeps populations, i.e.: Sumatera Thin Tail, Javanese Thin Tail, Javanese Fat Tail, Lembah Palu and Donggala. The Polymorphisms of exon 6 LCAT gene were induced by c.742 C>T (Figure 4a), c.770 T>A (Figure 4b) and c.883 C > T (Figure 4c).

Substitution of cytosine to thymine which was detected at c.742 was synonymous mutation, because it did not change amino acid (Ala>Ala). This mutation found in $\mathrm{H}_{2} \mathrm{H}_{2}$ (4 heads) and $\mathrm{H}_{4} \mathrm{H}_{10}$ (1 head), a total of 5 individuals dispersed on the Sumatera Thin Tail (2 heads); Garut (2 heads) and Lembah Palu (1 head). Heterozygous genotype (CT) found in $\mathrm{H} 1 \mathrm{H} 2$ and $\mathrm{H} 1 \mathrm{H} 4$ were found on Sumatera Thin Tail (1 head) and Javanese Thin Tail (4 heads). Synonymous SNPs could encode sequences with the same amino acid composition but structure and function changed (Komar, 2007).

Substitution of thymine to adenine at base c.770 and cytosine to thymine at base c. 882 were non-synonymous mutation, because they changed phenylalanine to isoleucine (Phe>Ile) and alanine to valine (Ala $>\mathrm{Val})$. Non Synonymous SNPs (nsSNPs) caused protein product changed and in humans, most associated with inherited diseases (Bao \& Cui, 2005).

At the base position of c.770 sheep with genotype AA was not found. Heterozygous genotype (AT) was found in five diplotypes, i.e.: $\mathrm{H} 1 \mathrm{H} 3, \mathrm{H} 3 \mathrm{H} 5, \mathrm{H} 5 \mathrm{H} 6, \mathrm{H} 1 \mathrm{H} 4$, and $\mathrm{H} 4 \mathrm{H} 10$ that were dispersed in many populations (Sumatera Thin Tail, Javanese Thin Tail, Lembah Palu, Javanese Fat Tail, and Garut). Genotype TT was found in four diplotypes, i.e.: $\mathrm{H} 1 \mathrm{H} 1, \mathrm{H} 1 \mathrm{H} 2, \mathrm{H} 1 \mathrm{H} 5$, and $\mathrm{H} 2 \mathrm{H} 2$.

SNP at base c.882 displayed three genotypes (CC, CT, and TT). CC genotype was found in 106 individuals that were scattered on the 5 diplotypes, i.e.: $\mathrm{H} 1 \mathrm{H} 1$, $\mathrm{H} 1 \mathrm{H} 2, \mathrm{H} 1 \mathrm{H} 3, \mathrm{H} 1 \mathrm{H} 4$, and $\mathrm{H} 2 \mathrm{H} 2$. Genotype $\mathrm{CT}$ was found in 3 diplotypes, i.e.: $\mathrm{H} 1 \mathrm{H} 5, \mathrm{H} 3 \mathrm{H} 5$, and $\mathrm{H} 4 \mathrm{H} 10$, while the TT genotype was found only in diplotipe H5H6. According to Nei \& Kumar (2000), in most nucleotide sequences there were more nucleotide sites that potentially produced synonymous and nonsynonymous sites vary from gene to gene.

The results showed that the spread of SNPs in Indonesian local sheep found in 6 sub-populations, except Kissar and Sumbawa were indicated monomorphic. High gene diversity was found in thin tail group (Sumatera Thin Tail and Javanese Thin Tail), followed by Garut and fat tail group. Crissa et al. (2010) reported 3 new SNPs in the LCAT gene of 3 breed sheeps (Altamurana, Gentile di Puglia, and Sarda) i.e.: g.181T >C, c.806G >A and c.1075T>C, with diversity gene that was relatively low.Each mutations that arise could affect molecular function through change to protein sta-

Table 1.Diplotypes of exon 6 in LCAT gene of Indonesian local sheeps at positions of 701 to 951 bases

\begin{tabular}{cccccc}
\hline \multirow{2}{*}{ Diplotype } & \multicolumn{3}{c}{ At bases } & n & $\begin{array}{c}\text { Frequency } \\
(\%)\end{array}$ \\
\cline { 2 - 4 } & c.742 & c.770 & c.883 & & CC \\
H1H1 & TT & CC & 78 & 66.10 \\
H1H2 & CT & TT & CC & 3 & 2.54 \\
H1H3 & CC & AT & CC & 19 & 16.10 \\
H1H4 & CT & AT & CC & 2 & 1.69 \\
H1H5 & CC & TT & CT & 6 & 5.08 \\
H2H2 & TT & TT & CC & 4 & 3.39 \\
H3H5 & CC & AT & CT & 4 & 3.39 \\
H4H10 & TT & AT & CT & 1 & 0.85 \\
H5H6 & CC & AT & TT & 1 & 0.85 \\
Total & & & & 118 & 100 \\
\hline
\end{tabular}

Notes: $\mathrm{n}=$ number of samples 


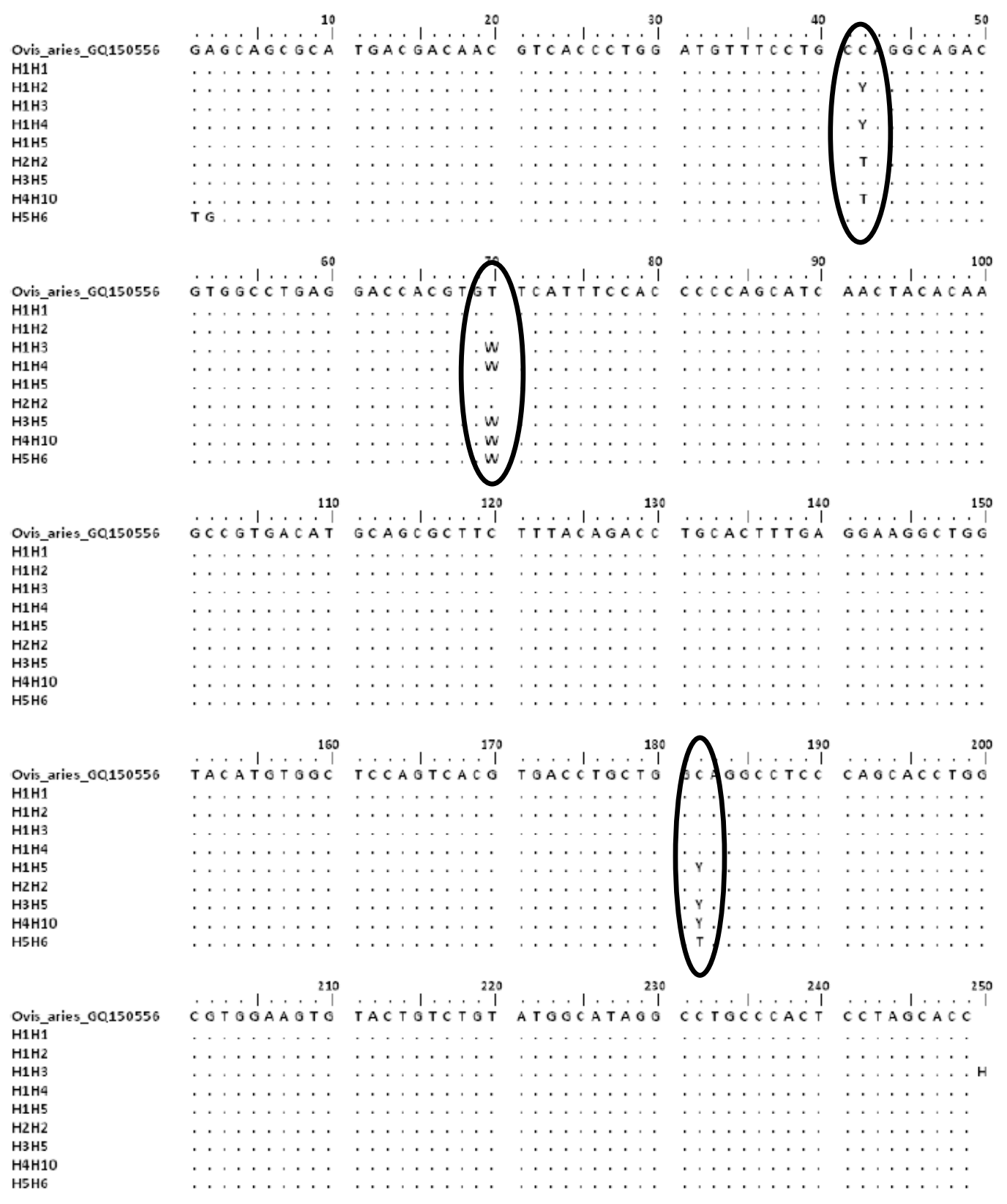

Figure 3. Alignmented LCAT gene at exon 6 in Indonesian local sheeps

bility and ligand binding protein, allosteric mechanisms and post-translational modification (Wang \& Moult, 2001; Teng et al., 2008). On the other hand, the roles of three point mutations in exon 6 of the LCAT gene in Indonesian Local sheep were not so well known. Crissa et al. (2010) was reported 3 new SNPs in the LCAT gene of 3 breed sheeps (Altamurana, Gentile di Puglia, and Sarda) i.e.: g.181T>C, c.806G $>$ A and c.1075T $>$ C, with diversity gene that was relatively low. The mutation at c.806 was a non-synonymous mutation (Asp to Asn) that has a negative effect on the ratio fatty acid C18:2 and C18:3 in milk of sheep (Crissa et al., 2010; Moioli et al., 2011). Qiao et al. (2010), showed that SNP at g.266 G>C in intron 1 was significantly associated with lean fat ratio, leaf fat weight or carcass length of three breed pigs and cholesterol level in blood plasma (Kaplanova et al., 2010).
LCAT reaction on lipoproteins consists of several steps; 1) binding lipoprotein/lipid surface by enzyme, 2) the activation of LCAT by apo lipoproteins 3) binding of lipid substrates 4) catalytic and finally 5) generate the lipid products (Jonas, 2000; Kaysen, 2007). The decrease of LCAT activity was implicated to cow's fertility decrease and fatty liver diseases (Uchida et al., 1995). Cholesterol esterification by LCAT is important for its transport from liver to peripheral tissues, such as corpus luteum. In addition, cholesterol serves as a substrate for progesterone synthesis in the other organ. The results of in vitro studies indicate the activation of LCAT by Apo A-I, but the exact mechanism is not known (Rousset et al., 2010).

Insertion of adenine results in a frameshift mutation at base g.214 in human, altering a large portion of LCAT enzyme, including both protein regions with putative 


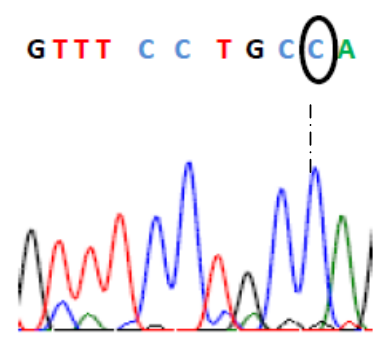

Figure 4a. SNP at basa c.742

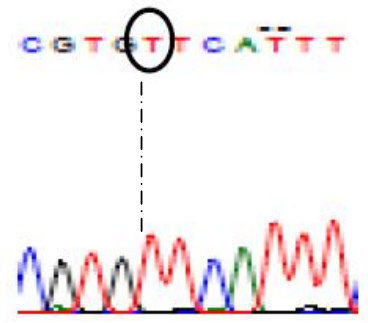

Figure $4 \mathrm{~b}$. SNP at basa c.770

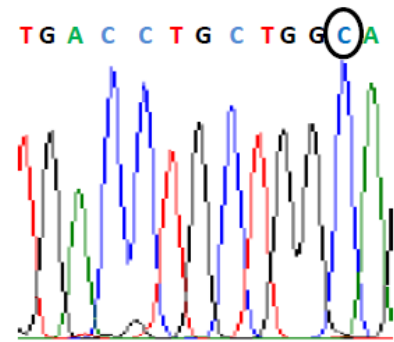

Figure $4 c$. SNP at basa c. 882
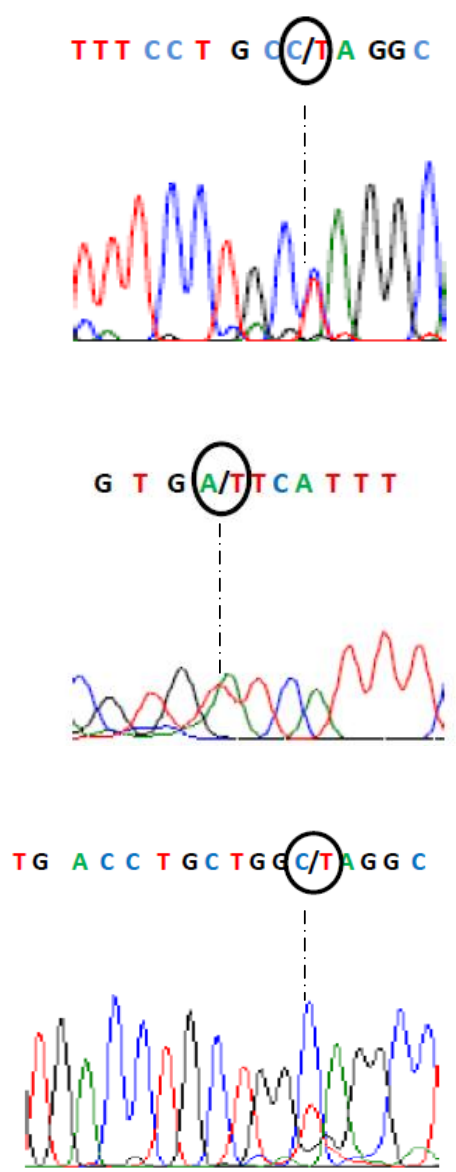

Figure 4. Partial sequencing maps of exon 6 of LCAT gene in Indonesian local sheep

lipase activity (Bender et al., 2007). Two mutations were detected in human LCAT that the Tyr ${ }^{83}$ (frameshift mutation) resulted in the synthesis of truncated 82 amino acid enzyme, which would be, if secreted, most likely non functional and the $\operatorname{Tyr}^{156}$ (Asn substitution) was formed an amphipathic helix, a residue within the hydrophobic phase of the helix resulting in a lower $\mathrm{pH}$ (Klein et al., 1993). LCAT enzyme was played on formation and maturation HDL and reverse cholesterol transport proses in intravascular (Savel et al., 2012). The absence of LCAT was resulted in the accumulation of free cholesterol in the blood and tissues (Qiao et al., 1997).

\section{The Frequencies of Gene, Genotype and Heterozygosity}

Frequency of gene or frequency of allele is a measure of the relative frequency of a particular gene/allele in a population (Nei \& Kumar, 2000). Genetic diversity within a population can be used as a parameter in studying the population and evolutionary genetics, identifiying genes that control the diversity of economic nature by the detection of positive alleles at locus having economic values to produce desirable traits (Sumantri et al., 2011).

The results showed a high gene diversity at locus c.742 found in Sumatera Thin Tail, Javanese Thin Tail, Garut, and Lembah Palu. The frequency of $\mathrm{C}$ gene was the predominat around $88.2 \%-98.8 \%$, and the frequency of $\mathrm{T}$ gene was around $1.2 \%-11.8 \%$ and those were indicated as a polymorphic loci (Table 2). The average frequency of genotype CC $(94.10 \%)$ was higher than CT $(3.2 \%)$ and TT $(2.7 \%)$ in all population. The SNPs loci were in Hardy-Weinberg disequilibrium in the Sumatera Thin Tail, Garut and Lembah Palu $(\mathrm{P}<0.01)$, except in The Javanese Thin Tail was in Hardy-Weinberg equilibrium. Genotype frequency deviations that can arise due to mutation, migration, selective mating and selection, could rapidly change genotype equilibrium that appears in a population. A population are in a Hardy-Weinberg equilibrium if genotype frequency and gene frequency constant from one generation to the next generation (Nei \& Kumar, 2000).

At the base c.770, it was found two types of genotypes (AT and TT), except on Kissar and Sumbawa only one genotype (TT). The frequency of TT genotype was higher than AT genotype on all population. The high frequency of TT genotype in the population resulted in a high frequency of T (76.5\%-94.2\%). The genotype frequencies at this SNP was fitted with Hardy-Weinberg equilibrium $(\mathrm{P}>0.05)$ on all population and the observation heterozygosity and expectation heterozygosity were relatively similar (Table 3 ).

Mutation at base c.882 C>T was found on Sumatera Thin Tail, Javanese Thin Tail, Garut, and Rote Island. The frequency of CC genotype $(89.6 \%)$ was higher than 
Table 2. Frequency of genotype and gene of LCAT gene exon 6 at base c. 742 in Indonesian local sheep

\begin{tabular}{|c|c|c|c|c|c|c|c|c|c|c|c|c|}
\hline \multirow{3}{*}{ Sub population } & \multirow{3}{*}{$\mathrm{n}$} & \multicolumn{11}{|c|}{ At base c.742 } \\
\hline & & \multicolumn{3}{|c|}{ Genotype frequency } & \multicolumn{2}{|c|}{ Gene frequency } & \multicolumn{3}{|c|}{ Genotype } & \multirow{2}{*}{$\begin{array}{l}\text { Equilibrium } \\
\quad \chi^{2} \text { test }\end{array}$} & \multirow{2}{*}{$\mathrm{H}_{\mathrm{o}}$} & \multirow{2}{*}{$\mathrm{H}_{\mathrm{e}}$} \\
\hline & & $\mathrm{CC}$ & $\mathrm{CT}$ & TT & C & $\mathrm{T}$ & $\mathrm{CC}(\mathrm{O} / \mathrm{E})$ & $\mathrm{CT}(\mathrm{O} / \mathrm{E})$ & $\mathrm{TT}(\mathrm{O} / \mathrm{E})$ & & & \\
\hline STT & 43 & 0.977 & 0.023 & 0.000 & 0.988 & 0.012 & $40 / 38.1176$ & $1 / 4.7647$ & $2 / 0.1176$ & $33.1852^{* *}$ & 0.023 & 0.1108 \\
\hline JTT & 17 & 0.765 & 0.235 & 0.000 & 0.882 & 0.118 & 13/13.1818 & $4 / 3.6364$ & 0/0.1818 & $0.2207^{\mathrm{ns}}$ & 0.235 & 0.2139 \\
\hline JFT & 6 & 1.000 & 0.000 & 0.000 & 1.000 & 0.000 & 1 & 0 & 0 & 0 & 0 & 0.0000 \\
\hline Garut & 19 & 0.895 & 0.000 & 0.105 & 0.895 & 0.105 & $17 / 15.1622$ & $0 / 3.6757$ & $2 / 0.1622$ & $24.727^{* *}$ & 0 & 0.1935 \\
\hline Lembah Palu & 9 & 0.889 & 0.000 & 0.111 & 0.889 & 0.111 & $8 / 7.0588$ & 0/1.8824 & $1 / 0.0588$ & $17.0667^{* *}$ & 0 & 0.2092 \\
\hline Rote Island & 7 & 1.000 & 0.000 & 0.000 & 1.000 & 0.000 & 1 & 0 & 0 & 0 & 0 & 0.0000 \\
\hline Kissar & 7 & 1.000 & 0.000 & 0.000 & 1.000 & 0.000 & 1 & 0 & 0 & 0 & 0 & 0.0000 \\
\hline Sumbawa & 10 & 1.000 & 0.000 & 0.000 & 1.000 & 0.000 & 1 & 0 & 0 & 0 & 0 & 0.0000 \\
\hline Mean & & 0.941 & 0.032 & 0.027 & 0.957 & 0.043 & & & & & 0.0323 & 0.0909 \\
\hline
\end{tabular}

Note: STT (Sumatera Thin Tail), JTT (Javanese Thin Tail), JFT (Javanese Fat Tail). ${ }^{* *}=$ significantly different at $\mathrm{P}<0.001$, ns $=$ non significant.

CT $(9.8 \%)$ and TT $(0.7 \%)$ (Table 4$)$. Based on equilibrium $\chi^{2}$ test, these genotype frequencies were on HardyWeinberg disequilibrium $(\mathrm{P}<0.01)$ on Sumatera Thin Tail, Javanese Thin Tail and Garut, except on Rote Island. This result is consistent with the results of heterozygosity analysis suggesting that the observed heterozygosity was lower than expectation heterozygosity.

These results showed a high polymorphisms of LCAT gene exon 6 in Indonesian Local sheep, excepted in Kissar and Sumbawa. The deviation of genotype frequencies were found at base c.742 (Sumatera Thin Tail, Garut, and Lembah Palu) and at base c.882 (Sumatera Thin Tail, Javanese Thin Tail, Garut, and Rote Island). The tendency of farmers to sell adult rams having a good performance as livestock, the practice of selective mating and the effective size of the population that is not balanced are suspected as factors causing low heterozygosity obtained in the population. High polymorphisms

Table 3. Frequency of genotype and gene of LCAT gene exon 6 at base c.770 in Indonesian local sheep

\begin{tabular}{|c|c|c|c|c|c|c|c|c|c|c|c|c|}
\hline \multirow{3}{*}{ Sub population } & \multirow{3}{*}{$\mathrm{n}$} & \multicolumn{11}{|c|}{ At base c.770 } \\
\hline & & \multicolumn{3}{|c|}{ Genotype frequency } & \multicolumn{2}{|c|}{ Gene frequency } & \multicolumn{3}{|c|}{ Genotype } & \multirow{2}{*}{$\begin{array}{l}\text { Equilibrium } \\
\chi^{2} \text { test }\end{array}$} & \multirow{2}{*}{$\mathrm{H}_{\mathrm{o}}$} & \multirow{2}{*}{$\mathrm{H}_{\mathrm{e}}$} \\
\hline & & AA & AT & TT & A & $\mathrm{T}$ & $\mathrm{AA}(\mathrm{O} / \mathrm{E})$ & $\mathrm{AT}(\mathrm{O} / \mathrm{E})$ & $\mathrm{TT}(\mathrm{O} / \mathrm{E})$ & & & \\
\hline STT & 43 & 0.000 & 0.116 & 0.884 & 0.058 & 0.942 & $0 / 0.1176$ & $5 / 4.7647$ & $38 / 38.1176$ & 0.1296 & 0.1160 & 0.1110 \\
\hline JTT & 17 & 0.000 & 0.471 & 0.529 & 0.235 & 0.765 & 0/0.8495 & $8 / 6.3030$ & 9/9.8485 & 1.3785 & 0.4710 & 0.3710 \\
\hline JFT & 6 & 0.000 & 0.167 & 0.833 & 0.083 & 0.917 & $0 / 0.000$ & $1 / 1.000$ & $5 / 5.000$ & 0 & 0.1667 & 0.1667 \\
\hline Garut & 19 & 0.000 & 0.316 & 0.684 & 0.158 & 0.842 & $0 / 0.4054$ & 6/5.1892 & 13/13.4054 & 0.5444 & 0.3158 & 0.2731 \\
\hline Lembah Palu & 9 & 0.000 & 0.333 & 0.667 & 0.167 & 0.833 & $0 / 0.1765$ & $3 / 2.6471$ & 6/6.1765 & 0.2286 & 0.3333 & 0.2941 \\
\hline Rote Island & 7 & 0.000 & 0.143 & 0.857 & 0.071 & 0.929 & $0 / 0.4615$ & $4 / 3.0769$ & $3 / 3.4615$ & 0.8000 & 0.5714 & 0.4396 \\
\hline Kissar & 7 & 0.000 & 0.000 & 1.000 & 0.000 & 1.000 & 0 & 0 & 1 & 0 & 0 & 0 \\
\hline Sumbawa & 10 & 0.000 & 0.000 & 1.000 & 0.000 & 1.000 & 0 & 0 & 1 & 0 & 0 & 0 \\
\hline Mean & & 0.000 & 0.193 & 0.807 & 0.0966 & 0.9034 & & & & & 0.2345 & 0.1990 \\
\hline
\end{tabular}

Note: STT (SumateraThin Tail), JTT (Javanese Thin Tail), JFT (Javanese Fat Tail).

Table 4. Frequency of genotype and gene of LCAT gene exon 6 at base c.882 in Indonesian local sheep

\begin{tabular}{|c|c|c|c|c|c|c|c|c|c|c|c|c|}
\hline \multirow{3}{*}{ Sub population } & \multirow{3}{*}{$\mathrm{n}$} & \multicolumn{11}{|c|}{ At base c. 882} \\
\hline & & \multicolumn{3}{|c|}{ Genotype frequency } & \multicolumn{2}{|c|}{ Gene frequency } & \multicolumn{3}{|c|}{ Genotype } & \multirow{2}{*}{$\begin{array}{l}\text { Equilibrium } \\
\chi^{2} \text { test }\end{array}$} & \multirow{2}{*}{$\mathrm{H}_{\mathrm{o}}$} & \multirow{2}{*}{$\mathrm{H}_{\mathrm{e}}$} \\
\hline & & $\mathrm{CC}$ & $\mathrm{CT}$ & TT & C & $\mathrm{T}$ & $\mathrm{CC}(\mathrm{O} / \mathrm{E})$ & $\mathrm{CT}(\mathrm{O} / \mathrm{E})$ & $\mathrm{TT}(\mathrm{O} / \mathrm{E})$ & & & \\
\hline STT & 43 & 0.930 & 0.070 & 0.000 & 0.970 & 0.030 & $35 / 30.9176$ & $3 / 11.1647$ & $5 / 0.9176$ & $24.6711^{* *}$ & 0.0698 & 0.2596 \\
\hline JTT & 17 & 0.824 & 0.176 & 0.000 & 0.912 & 0.088 & $10 / 7.6667$ & $3 / 7.6667$ & 4/1.6667 & $6.8174^{* *}$ & 0.177 & 0.451 \\
\hline JFT & 6 & 1.000 & 0.000 & 0.000 & 1.000 & 0.000 & 1 & 0 & 0 & 0 & 0 & 0 \\
\hline Garut & 19 & 0.842 & 0.105 & 0.053 & 0.895 & 0.105 & $16 / 15.1622$ & $2 / 3.6757$ & $1 / 0.1622$ & $5.139^{* *}$ & 0.1053 & 0.1935 \\
\hline Lembah Palu & 9 & 1.000 & 0.000 & 0.000 & 1.000 & 0.000 & 1 & 0 & 0 & 0 & 0 & 0.0000 \\
\hline Rote Island & 7 & 0.571 & 0.429 & 0.000 & 0.786 & 0.214 & $4 / 4.2308$ & $3 / 2.5385$ & $0 / 0.2308$ & $0.3273^{\text {ns }}$ & 0.4286 & 0.3626 \\
\hline Kissar & 7 & 1.000 & 0.000 & 0.000 & 1.000 & 0.000 & 1 & 0 & 0 & 0 & 0 & 0 \\
\hline Sumbawa & 10 & 1.000 & 0.000 & 0.000 & 1.000 & 0.000 & 1 & 0 & 0 & 0 & 0 & 0 \\
\hline Mean & 118 & 0.896 & 0.098 & 0.007 & 0.9490 & 0.05097 & & & & & 0.0931 & 0.0948 \\
\hline
\end{tabular}

Note: STT (Sumatera Thin Tail), JTT (Javanese Thin Tail), JFT (Javanese Fat Tail). ${ }^{* *}=$ significantly different at P<0.001, ns= non significant. 
genes of Indonesian Local Sheeps were reported in calpastatin gene (Sumantri et al., 2008b; Dagong et al., 2011) and no polymorphism was detected in myostatin gene (Sumantri et al., 2011).

\section{CONCLUSION}

Three SNPs in the LCAT gene were detected at the c.742 C>T; c.770 T >A and c.882 C>T. The combination of these three SNPs formed nine diplotypes. Substitution of cytosine to thymine c.742 is synonymous mutation (alanine>alanine); thymine to adenine c.770 and cytosine to thymine c.882 are non-synonymous mutation that change phenylalanine $>$ isoleucine and valine $>$ alanine. Polymorphisms of LCAT gene exon 6 was found in Sumatera Thin Tail, Javanese Thin Tail, Javanese Fat Tail, Garut, Lembah Palu, and Rote Island. Further research needs to be done to determine the expression of LCAT gene diversity in the three new SNPs and its relationship to the meat fat quality.

\section{ACKNOWLEDGEMENT}

Thanks to the Institute Research and Community Service UIN Suska Riau for providing a financial support through the rector's decree No. 988/R/2013.

\section{REFERENCES}

Bao, L. \& Y. Cui. 2005. Prediction of the phenotypic effects of non-synonymous single nucleotide polymorphisms using structural and evolutionary information. J. Bioinformatics 21: 2185-2195. http://dx.doi.org/10.1093/bioinformatics/ bti365

Bender, B. U., T. Quaschning, H. P. H. Neumana, D. Schmidt, \& A. K. Guth. 2007. A novel frameshift mutation of the lecithin cholesterol acyltransferase (LCAT) gene associated with renal failure in familial LCAT deficiency. CCLM 45:483-486. http://dx.doi.org/10.1515/CCLM.2007.102

Chalupova, P., T. Sedlackova, K. Kaplanova, F. Weisz, M. Bryndova, Z. Vykoukalova, M. Juzl, H. Sulcerova, T. Gregor, T. Urban, P. Slama \& A. Knoll. 2010. Association of 15 candidate genes with meat quality traits in Czech Large White pigs. African Journal of Agricultural Research 7(25): 3719-3728. http://dx.doi.org/10.5897/ AJAR11.2144

Chen, R. J., Z. P. Yang, D. J. Ji, D.Y. Qu, Y. L. Li, Y. J. Mao, \& D. L. Huang. 2009. Analysis of genetic polymorphism in six meat sheep breeds and genetic distances between them. Czech J. Anim. Sci. 54:461-467.

Costa, R. G., A. S. M. Batista, P. S. Azevedo, R. C. R. E. Queiroga, M. S. Madruga, \& J. T. A. Filho. 2009. Lipid profile of lamb meat from different genotypes submitted to diets with different energy levels. R. Brass. Zootec. 38: 532-538. http://dx.doi.org/10.1590/S1516-35982009000300019

Crisa, A., C. Marchitelli, L. Pariset, G. Gontarini, F. Signarelli, R. Napolitano, G. Catillo, A.Valentini, \& B. Moili. 2010. Exploring polymorphism and effects of candidate genes on milk fat quality in dairy sheep. J. Dairy Sci. 93:38343845. http://dx.doi.org/10.3168/jds.2009-3014

Dagong, M. I. A., C. Sumantri, R. R. Noor, R. Herman, \& M. Yamin. 2011. Genetic polymorphisms of the coding region $\left(6^{\text {th }}\right.$ exon) of calpastatin (CAST) in Indonesian sheep. Med. Pet. 34: 190-195. http://dx.doi.org/10.5398/medpet.2011.34.3.190

De Smet, S., K. Raes, \& D. Demeyer. 2004. Meat fatty acid composition as affected by fatness and genetic factors: a review. Anim. Res. 53: 81-98. http://dx.doi.org/10.1051/animres:2004003

Dunner, S., N. Sevane, D. Garcia, O. Cortes, A. Valentini, J. L. Williams, B. Mangin, J. Canon, H. Leveziel \& T. G. Consortium. 2013. Association of genes involved in carcass and meat quality traits in 15 European bovine breed. Livestock Sci. 154(2013): 34-44.

Food and Agriculture Organisation (FAO). 2002. Conserving and Developing Farm Animal Diversity. Rome: Secretariat of the report on the state of the world's animal genetics resources.

Hall, T. 2011. BioEdit; An important software for molecular biology. GERF Bulletin of Bioscience 2: 60-61.

Inounu, I. 2011. Pembentukan domba komposit melalui teknologi persilangan dalam upaya peningkatan mutu genetik domba lokal. J. Pengembangan Inovasi Pertanian 4: 218-230.

Jakaria, M. S. A. Zein, Sulandari, Subandriyo, \& Muladno. 2012. The use of microsatellite markers to study genetic diversity in Indonesian Sheep. JITAA. 37: 1-9.

Jonas, A. 2000. Lecithin cholesterol acyltransferase. Biochim BiophysActa. 1529:245-56. http://dx.doi.org/10.1016/S13881981(00)00153-0

Kaplanova, K., M. Bryndova, F. Weisz, T. Urban, H. Sulcerova, M. Juzl, \& P. Slama. 2010. Single Nucleotide Polymorphisms in LCAT, HMGCR, CTSZ and TCF7L2 genes with influence on meat quality traits in Czech large white pigs. MendelNet 2010: 880-887.

Kaysen, GA. 2007. Dialysis removes apolipoprotein C-I, improving very low-density lipoprotein clearance. Kidney International 72: 779-7781. http://dx.doi.org/10.1038/ sj.ki.5002478

Klein, H. G., P. Lohae, N. Duverger, J. J. Albers, D. J. Rader, L. A. Zech, S. S. Fojo, \& H. B. Brewer. 1993. Two different allelic mutations in the lecithin cholesterol acyltransferase (LCAT) gene resulting in classic LCAT deficiency LCAT $\left(\right.$ tyr $^{83} \rightarrow$ stop) and LCAT (tyr ${ }^{156} \rightarrow$ asn). J Lipid Res. 34: 49-58.

Komar, A. A. 2007. Silent SNPs: Impact on gene function and phenotype. Phamacogenomic 8: 1075-1080. http://dx.doi. org $/ 10.2217 / 14622416.8 .8 .1075$

Kromhout, D., A. Menotti, B. Blomberg, C. Aravanis, H. Blackburn, R. Buzing, A. S. Dontas, F. Fidanza, S. Giampaoh, \& A. Jansen. 1995. Dietary saturated and trans fatty acids and cholesterol and 25-year mortality from coronary heart disease: the Seven Countries Study. Prev. Med. 24: 308315. http://dx.doi.org/10.1006/pmed.1995.1049

Kumar, S., K. Tamura, \& M. Nei. 2004. MEGA3: Integrated software for molecular evolutionary genetics analysis and sequence alignment. Brief. Bioinform. 5: 150-163. http:// dx.doi.org/10.1093/bib/5.2.150

Lin, D. Y \& D. Zeng. 2006. Likelihood-based inference on haplotype effects in genetic association studies. Journal of the American Statistical Association. 101( 473) , 89-118 http:// dx.doi.org/ 10.1198/016214505000000808

Loor,J. J., R. E. Everts, M. Bionaz, H. M. Dann, D. E. Morin, R. Oliveira, S. L. R. Zas, J. K. Drackley \& H. A. Lewin. 2007. Nutrition-induced ketosis alters metabolic and signaling gene networks in liver of periparturient dairy cows. Physiol. Genomics. 32: 105-116.

Moioli, B., G. Contarini, L. Pariset, C. Marchitelli, A. Crisa, G. Catilo, \& F. Napolitano. 2012. Genetic variation of C18:1 and C18:2 isomers in sheep milk fat. Small Rumin. Res. 103: 187-193. http://dx.doi.org/10.1016/j.smallrumres.2011 .08 .009

Nei, M. \& S. Kumar. 2000. Molecular Evolution and Phylogenetics. Oxford University Press, New York.

Qiao, M., H. Y. Wu, F. E. Li, S. W. Jiang, Y. Z. Xiong, \& C. Y. Deng. 2010. Molecular characterization expression profile and association analysis with carcass traits of porcine 
LCAT gene. Mol. Biol. Rep. 37: 2227-2234. http://dx.doi. org/10.1007/s11033-009-9709-x

Reinshagen, V.H., J.Dokin, S. Stukas, J.Chan, A. Wilkinson, J.Fan., J.S. Parks, J.A Kuivenhoven, D. Lutjohann, H.Pritchard \& C.L.Wellington. 2009. LCAT synthesized by primary astrocytes esterifies cholesterol on glia-derived lipoproteins. Journal of Lipid Research 50: 885-893.http:// dx.doi.org/10.1194/jlr.M800584-JLR200

Rousset, X., B. Vaisman, M. Amar, A. A. Sethi, \& A. T. Remaley. 2010. Lecithin: cholesterol acyltransferase: from biochemistry to role in cardiovascular disease. Curr. Opin. Endcrinol. Diabetes Obes. 16: 163-171. http://dx.doi.org/10.1097/ MED.0b013e328329233b

Sambrook, J., E. F. Fritsch, \& T. Maniatis. 1989. Molecular Clonning: A laboratory manual. $2^{\text {nd }}$ Ed. Cold Spring Harbor Laboratory Press, USA.

Savel, J., M. Lafitte, Y. Pucheu, V. Pradeau, A. Tabarin, \& T. Couffinhal. 2012. Very low levels of HDL cholesterol and atherosclerosis, a variable relationship- a review of LCAT deficiency. Vascular Health and Risk Management. 8:357361.

Sumantri, C., A. Einstiana, J. F. Salamena, \& I. Inounu. 2007. Keragaan dan hubungan phylogenic antar domba lokal di Indonesia melalui pendekatan analisis morfologi. JITV 12: 42-54.

Sumantri, C., A. Farajallah, U. Fauzi, \& J. F. Salamena. 2008a. Keragaman genetic DNA microsatellite dan hubungannya dengan performa bobot badan pada domba lokal Indonesia. Med. Pet. 31: 1-13.

Sumantri, C., R. Diyono, A. Farajallah, \& I. Inounu. 2008b. Polimorfisme gen calpastatin (CAST-Msp1) dan pengaruhnya terhadap bobot hidup domba lokal. JITV 13: 117-126.

Sumantri, C. Jakaria, M. Yamin, H. Nuraini, \& E. Andreas. 2011. Identicication of Myostatin gene c.960delG locus polymorphism in Indonesian Local Sheep by using PCRSSCP Method. JITAA 36: 145-151.
Tamura K., J. Dudley, M. Nei, \& S. Kumar. 2007. Mega4: Molecular Evalutionary Genetics Analysis (MEGA) Software Version 4.0. Mol. Biol. Evol. 24:1596-1599. http://dx.doi. org $/ 10.1093 / \mathrm{molbev} / \mathrm{msm} 092$

Teng, S., E. M. Alexova, \& E. Alexov. 2008. Approaches and resources for prediction of the effects of non-synonymous single nucleotide polymorphism on protein function and interactions. Curr. Pharm. Biotechno. 9: 123-133. http:// dx.doi.org/10.2174/138920108783955164

Uchida, E., N. Katoh, \& K. Takahashi. 1995. The activity of lecithin: cholesterol acyltransferase in the serum cows at parturition or with fatty liver. Vet. Res. Commun. 19: 343-351. http://dx.doi.org/10.1007/BF01839316

Wang, Z. \& J. Moult. 2001. SNPs, protein structure and disease. Hum. Mutat. 17: 263-270. http://dx.doi.org/10.1002/ humu.22

Wheeler, T. L., G. W. Davis, B. J. Stocker, \& C. J. Hammond. 1987. Cholesterol concentration of Longissimus dorsi, subcutaneous fat and serum of two beef cattle breed type. J. Anim. Sci. 65: 1531-1537.

Wood, J. D., M. Enser, A. V. Fisher, G. R. Nute, P. R. Sheard, R. I. Richardson, S. I. Hughes, \& F. M. Whittington. 2008. Fat deposition, fatty acid composition and meat quality: A Review. Meat Sci. 78: 343-358. http://dx.doi.org/10.1016/ j.meatsci.2007.07.019

Yeh, F. C., R. C. Yang, \& T. Boyle. 1999. POPGENE Version 1.31: Microsoft Window-Based Freeware for Population Genetic Analysis. Canada University of Alberta (CAN). Edmonton, $\mathrm{AB}$.

Zhao, S., J. Wang, X. Song, X. Zhang, C. Ge, \& S. Gao. 2010. Impact of dietary protein on lipid metabolism-related gene expression in porcine adipose tissue. Nutr. Metab. 7:6. http://dx.doi.org/10.1186/1743-7075-7-6 